\title{
Budget of Primary Production and Dinitrogen Fixation in a Highly Seasonal Red Sea Coral Reef
}

\author{
Ulisse Cardini $\odot,{ }^{1,2 *}$ Vanessa N. Bednarz, ${ }^{1}$ Nanne van Hoytema, ${ }^{1}$ \\ Alessio Rovere, ${ }^{3}$ Malik S. Naumann, ${ }^{1}$ Mamoon M. D. Al-Rshaidat,${ }^{4,5}$ \\ and Christian Wild ${ }^{1,6}$
}

${ }^{1}$ Coral Reef Ecology Group, Leibniz Center for Tropical Marine Ecology (ZMT), Fahrenheitstr. 6, 28359 Bremen, Germany; ${ }^{2}$ Division of
Microbial Ecology, Department of Microbiology and Ecosystem Science, Research Network Chemistry meets Microbiology, University
of Vienna, Althanstrasse 14, 1090 Vienna, Austria; ${ }^{3}$ Sea Level and Coastal Changes Group, Leibniz Center for Tropical Marine Ecology
(ZMT) and MARUM - Center for Marine Environmental Sciences and Faculty of Geosciences, University of Bremen, 28334 Bremen,
Germany; ${ }^{4}$ Laboratory for Molecular Microbial Ecology (LaMME), Marine Science Station, Aqaba 77110 , Jordan; ${ }^{5}$ Department of
Marine Biology, The University of Jordan - Aqaba Branch, Aqaba 77110, Jordan; ${ }^{6}$ Faculty of Biology and Chemistry (FB 2), University Marine Biology, The University of Jordan - Aqaba Branch, Aqaba 77110, Jordan; ${ }^{6}$ Facult
of Bremen, 28359 Bremen, Germany

\begin{abstract}
Biological dinitrogen $\left(\mathrm{N}_{2}\right)$ fixation (diazotrophy, $\mathrm{BNF}$ ) relieves marine primary producers of nitrogen $(\mathrm{N})$ limitation in a large part of the world oceans. $\mathrm{N}$ concentrations are particularly low in tropical regions where coral reefs are located, and $\mathrm{N}$ is therefore a key limiting nutrient for these productive ecosystems. In this context, the importance of diazotrophy for reef productivity is still not resolved, with studies up to now lacking organismal and seasonal resolution. Here, we present a budget of gross primary production (GPP) and BNF for a highly seasonal Red Sea fringing reef, based on ecophysiological and benthic cover measurements combined with geospatial analyses. Benthic GPP varied from 215 to $262 \mathrm{mmol} \mathrm{C} \mathrm{m}^{-2}$ reef $\mathrm{d}^{-1}$, with hard corals making the largest contribution (41-76\%). Diazotrophy was
\end{abstract}

Received 5 August 2015; accepted 18 December 2015

published online 16 March 2016

Electronic supplementary material: The online version of this article (doi:10.1007/s10021-016-9966-1) contains supplementary material, which is available to authorized users.

Author contributions $\mathrm{CW}, \mathrm{UC}, \mathrm{VNB}, \mathrm{NvH}$, and MSN designed the study; UC, VNB, NvH performed the research; UC analyzed the data; AR contributed with the GIS analysis; MMDAR supervised during field-work activities; UC wrote the manuscript with input from all authors.

*Corresponding author; e-mail: ulisse.cardini@gmail.com omnipresent in space and time, and benthic BNF varied from 0.16 to $0.92 \mathrm{mmol} \mathrm{N} \mathrm{m}^{-2}$ reef $\mathrm{d}^{-1}$. Planktonic GPP and BNF rates were respectively approximately 60 - and 20 -fold lower than those of the benthos, emphasizing the importance of the benthic compartment in reef biogeochemical cycling. BNF showed higher sensitivity to seasonality than GPP, implying greater climatic control on reef BNF. Up to about $20 \%$ of net reef primary production could be supported by BNF during summer, suggesting a strong biogeochemical coupling between diazotrophy and the reef carbon cycle.

Key words: Diazotrophy; Photosynthesis; Productivity; Nutrient budget; Biogeochemical cycling; Gulf of Aqaba.

\section{INTRODUCTION}

Nitrogen $(\mathrm{N})$ is a fundamental component of all living organisms. In particular, $\mathrm{N}$ is needed by primary producers in capturing energy through photosynthesis and building biomass, leading to a tight coupling of the $\mathrm{N}$ and carbon (C) cycles (Gruber and Galloway 2008) and dictating constraints to the 
flexibility of the ecosystem C:N stoichiometry (Geider and La Roche 2002). In unperturbed and oligotrophic marine systems, primary productivity is often limited by bioavailable forms of $\mathrm{N}$, which are scarce due to low atmospheric inputs and $\mathrm{N}$ loss pathways (Vitousek and Howarth 1991). This limitation is of particular significance in coral reef ecosystems, as these are among the ecosystems displaying the highest rates of gross primary production (GPP), yet experiencing very low ambient concentrations of dissolved nutrients. Here, biological dinitrogen $\left(\mathrm{N}_{2}\right)$ fixation (diazotrophy, BNF) is thought to play an important role in replenishing the $\mathrm{N}$ pool, maintaining the ecosystem productivity and its biological storage of $\mathrm{C}$ ( $\mathrm{D}^{\prime}$ Elia and Wiebe 1990; Capone 1996; O'Neil and Capone 2008).

Since the early work by Wiebe and others (1975) on BNF in algal reef flats of the Marshall Islands, many studies have found high rates of BNF associated with several benthic substrates, ranging from sediments and cyanobacterial mats to macroalgae and scleractinian corals (for reviews, see $\mathrm{O}^{\prime} \mathrm{Neil}$ and Capone 2008; Cardini and others 2014). Moreover, after first evidence of a diazotroph-coral association by Shashar and others (1994a) and the subsequent discovery of diazotrophic cyanobacteria in the tissue of scleractinian corals of the genus Montastraea (Lesser and others 2004), there has been emergent recognition of the potential contribution of $\mathrm{N}_{2}$ fixing symbioses in coral reefs (Fiore and others 2010; Cardini and others 2014). Although reef sediments and cyanobacterial mats show high rates of BNF (O'Neil and Capone 1989; Capone and others 1992; Shashar and others 1994b; CharpyRoubaud and others 2001; Bednarz and others 2015b), $\mathrm{N}_{2}$-fixing coral symbioses may also be responsible for significant inputs of $\mathrm{N}$ on the ecosystem level, particularly in reef habitats with high live coral coverage.

BNF in coral reef habitats is highly variable (O'Neil and Capone 2008) and potentially affected by global and local anthropogenic disturbances (Cardini and others 2014). Therefore, it is increasingly important to quantify BNF at the reef scale, and under changing environmental conditions, if we want to understand how diazotrophy is contributing to the functioning of reef ecosystems. Because of the uncertainty in (1) the distribution of BNF in coral reefs and in (2) the tightness of the coupling between BNF and primary production, the ecological significance of BNF in coral reef ecosystems is still not resolved, demonstrating the difficulty in determining BNF rates for whole communities (Cuet and others 2011). Thus, the objective of this paper is to provide an assessment of the quantitative importance of the process of BNF for primary production in coral reef ecosystems. Although some studies have attempted this before (Capone and Carpenter 1982; Larkum and others 1988; Capone 1996; Casareto and others 2008), no systematic and comprehensive analyses considering the complex diversity of coral reef substrates have been performed so far that would allow for a synthesis. In particular, questions that we target are: (1) What is the relative contribution of key individual benthic categories to overall reef GPP and BNF? (2) How much are different benthic reef habitats contributing to these two processes, and is the water column contributing significantly? (3) To what extent is reef BNF important in sustaining net reef primary production (NPP)? (4) Are reef GPP and BNF affected by seasonality, and by seasonal shifts in benthic assemblages?

We address these questions using results from a year-long study at a highly seasonal fringing reef in the northern Red Sea, combining ecophysiological GPP and BNF measurements of all key benthic players with benthic surveys and environmental monitoring in high temporal resolution. Moreover, geographic information system (GIS) analyses allowed us to investigate the relative importance of all reef-associated habitats to total reef GPP and BNF. Finally, we indicate the most probable environmental factors driving BNF in coral reef habitats, and provide revised estimates of reef-wide $\mathrm{BNF}$, with consequent implications for management and for predicting the potential effects of human alterations on reef biogeochemical cycling.

\section{Materials AND Methods}

\section{Study Site}

This study was carried out at a northern Red Sea fringing reef (Aqaba, Jordan) during two expeditions (January-April 2013 and August-December 2013). Four sampling campaigns, each encompassing 3 weeks, were undertaken in February, April, September, and November, respectively. The timing of these periods (hereinafter called winter, spring, summer, and autumn, respectively) was determined from literature to best cover the annual diversity of environmental conditions in this area of the Red Sea. In fact, the Gulf of Aqaba is characterized by an annual cycle of deep water mixing from December until May and stratification down to $200 \mathrm{~m}$ water depth from June until November (Silverman and others 2007; Carlson and others 2014). All measurements were conducted on site in the aquarium and laboratory facilities of the Mar- 
ine Science Station (MSS, University of Jordan; location: $29^{\circ} 27^{\prime} \mathrm{N}, 34^{\circ} 58^{\prime} \mathrm{E}$ ). Monitoring and sample collection took place on the adjacent fore reef slope at $10 \mathrm{~m}$ water depth. The fringing reef system extends approximately $1.1 \mathrm{~km}$ along its reef crest bordering the coastline. This reef has the typical morphology and zonation of Red Sea fringing reefs, and can be partitioned into a reef flat, a reef crest and slope (hereafter: reef crest), and a fore reef facing the open sea (Mergner and Schuhmacher 1974; Naumann and others 2012b). The fore reef consists of an upper, middle, and lower part characterized by distinctive morphological features and species composition (hereafter: sand belt, transition zone, and fore reef). The present study focuses on the reef area framed by the reef flat and the fore reef slope at the maximum investigated depth (depth range: $0.5-20.0 \mathrm{~m}$ ).

\section{Environmental Monitoring}

Key environmental parameters were continuously monitored at the sampling site during all seasons. Light availability and water temperature were measured with data loggers (Onset HOBO Pendant UA002-64; temperature accuracy: $\pm 0.53^{\circ} \mathrm{C}$, spectral detection range $150-1200 \mathrm{~nm}$ ) and a quantum sensor (Model LI-192SA; Li-Cor). Light measurements are presented as total mole of photons per square meter per day, while temperature values are daily $(24 \mathrm{~h})$ averages. Sampling for dissolved inorganic nitrogen (DIN $\left.=\mathrm{NH}_{4}{ }^{+}+\mathrm{NO}_{x}\right)$, dissolved inorganic phosphorous (DIP), chlorophyll $a$ (Chl $a$ ), dissolved organic carbon (DOC), particulate organic carbon (POC), and particulate nitrogen (PN) was carried out once a week by SCUBA. For a detailed explanation of the analytical procedures, please refer to Bednarz and others (2015b) and Rix and others (2015).

\section{Benthic Community Composition}

Line-point intercept (LPI) surveys were conducted to quantify benthic community composition and to identify the dominant benthic categories. In each season, three LPI, each of $50 \mathrm{~m}$ length, were carried out at $0.5,1.0,5.0,10.0$, and $20.0 \mathrm{~m}$ water depth, at increasing distance from land along transects parallel to the shoreline, both in the north and south sections of the reef. This accounted for a total of 120 LPIs. The transect water depths were selected as in previous studies (Naumann and others $2012 \mathrm{~b}$ ) to include all major reef habitats and to be representative of the seafloor coverage by all dominant benthic categories. Intervals of $0.5 \mathrm{~m}$ between intercepts resulted in 101 data points per LPI. Results obtained from all LPI in each water depth were used to calculate the percentage coverage for each reef habitat (that is, reef flat, reef crest, sand belt, transition zone, and fore reef) in each season (Table S1), and to select the benthic categories to be subsequently incubated that together accounted on average for ca. $90 \%$ of the slope 2D reef area (Figure S3, Table S2, S3).

\section{Reef Bathymetry and Zonation}

Bathymetric contours were obtained by merging data from the Aqaba Special Economic Zone Authority (ASEZA) GIS Unit and original bathymetric data obtained in the field, overlaid onto a high-resolution satellite image (c) Digital Globe). Bathymetric contours were subsequently processed into a continuous raster using the ArcGis Topo to Raster tool (ESRI ArcGis ${ }^{\circledR}$ ), with the final raster having a cell size of approximately $2.9 \mathrm{~m}$. The habitat map was produced based on prior knowledge of the reef zonation (Mergner and Schuhmacher 1974), on the interpretation of the highresolution satellite image, and on ground truthing during the LPI surveys. Finally, zonal statistics referring to the bathymetric raster were calculated for each habitat using ArcGis 3D Analyst tools. The slope $2 \mathrm{D}$ area (that is, considering the depth profile, see Figure S3) for each habitat was obtained from the planar 2D area using the bathymetric raster as base layer. The bathymetric and habitat maps are presented in Figure 1, and zonal statistics for each habitat are reported in Table S2 and were used in our subsequent ecological analyses.

\section{Sample Collection and Maintenance}

All benthic categories were sampled on the reef and transported back to the MSS facilities within 60 min of sampling. For an overview and description of the categories incubated and respective replication, see Table S3. Hard and soft corals, as well as turf algae covered branches, were fixed to ceramic tiles while coral rock fragments were stable without fixation. Macroalgae were fixed to Petri dishes with rubber bands, protecting the algal tissue from crushing. Sediment and cyanobacterial mat samples were collected with cylindrical sediment corers (internal diameter $=43 \mathrm{~mm}$ ) and the top $1 \mathrm{~cm}$ of the core was extruded and placed in a Petri dish with the same internal diameter as the sediment corer. Coral rock was defined as pieces of biogenic reef framework with the carbonate structure clearly visible and open for settling organisms. Categories (such as coral rock and sediment) are hereafter defined 'bare' when they lack coverage by a dominant and visible epibenthic group and the 


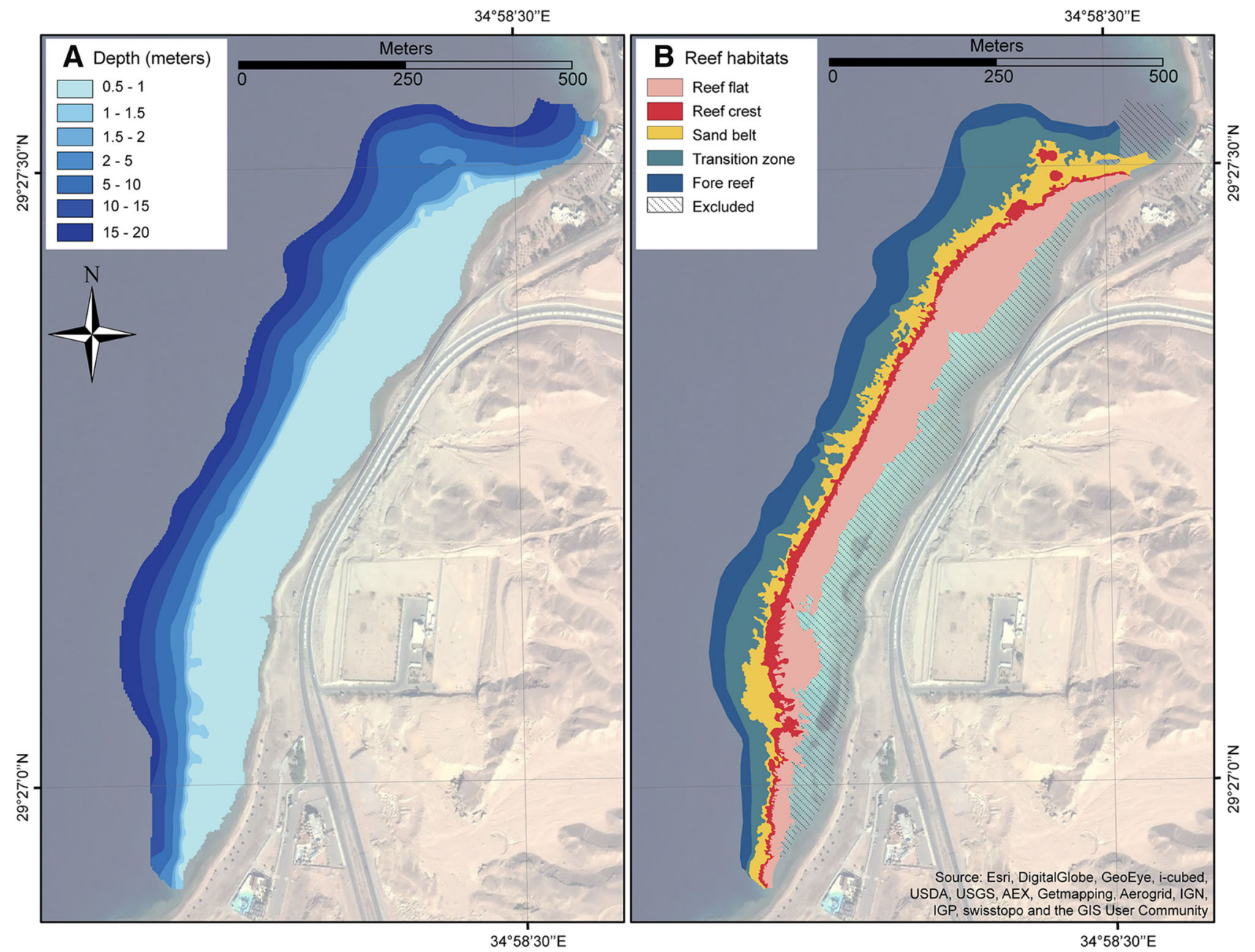

Figure 1. Bathymetry (A) and reef habitat (B) maps of the study site.

substrate is open for settling organisms although being associated with endobenthic algae, microbial biofilms, and sparse patches of crustose coralline algae (CCA), cyanobacteria, and filamentous algae (Rix and others 2015). All organisms and substrates were maintained in an outside flow-through aquarium of $800 \mathrm{~L}$ with an exchange rate of $4000 \mathrm{~L} \mathrm{~h}^{-1}$. Water was pumped straight from the reef at $10 \mathrm{~m}$ water depth, thus resembling in situ conditions of temperature and inorganic nutrients. In situ light conditions at $10 \mathrm{~m}$ water depth were generated using layers of black mesh and monitored with Onset HOBO data loggers. Hard and soft corals were maintained for at least 7 days, and macroalgae for at least $24 \mathrm{~h}$, to recover from the collection process. Sediment, turf algae, coral rock, and cyanobacterial mats were incubated on the day of collection.

\section{Surface Area Quantification}

The 3D surface areas of all benthic categories were quantified using various tools. 3D surface areas of hard and soft corals, turf algae, and coral rock were measured using Advanced Geometry (Naumann and others 2009; Bednarz and others 2015a). Macroalgae surface areas were assessed by digital image analysis of planar photographs using ImageJ v.1.48 (Schneider and others 2012), and doubling the one-sided surface area to obtain the total 3D specimen surface area as described in Haas and others (2010). Sediment and cyanobacterial mat surface areas were calculated from the circular surface area sampled by the sediment corer. Average 3D surface area for each benthic category (see Table S3 for information on replication for each category) calculated as described above, was related 
to the planar projected 2D area of the same specimens quantified by digital image analysis to generate $2 \mathrm{D}$ to $3 \mathrm{D}$ area conversion factors (Naumann and others 2012b) as reported in Table S3. These conversion factors were subsequently used to calculate the benthic 3D area available to photosynthetic and/or $\mathrm{N}_{2}$-fixing organisms (Figure S3), and to extrapolate our physiological measurements to the reef ecosystem scale (Table S4). The normalization (surface area) and extrapolation (2D:3D conversion) methods used here, although being simple, yields good estimates of the target processes while allowing calculations of areal rates and best comparability of the present data to previous studies (for example, Larkum and others 1988; Eidens and others 2014).

\section{Physiological Measurements}

Specimens were incubated for measurements of NPP, dark respiration (R), and BNF. For a detailed explanation of the incubation and analytical procedures, please refer to Bednarz and others (2015b) and Rix and others (2015). Briefly, incubations were conducted under in situ conditions in a flowthrough aquarium in closed glass chambers $(0.5-$ $1.0 \mathrm{~L})$. Magnetic stirrer plates $\left(\operatorname{Cimarec}^{\mathrm{TM}} \mathrm{i}\right.$ Telesystem Multipoint Stirrers, Thermo Scientific $^{\mathrm{TM}}$ ) and Teflon-coated stir bars in the chambers provided water movement during the incubations at $600 \mathrm{rpm}$. All material used to fix organisms was thoroughly cleaned before each incubation with a fine brush to remove potential epi-biota. NPP and R of each specimen were quantified by their respective oxygen $\left(\mathrm{O}_{2}\right)$ fluxes in the light and in the dark with a conductivity- and temperature-corrected $\mathrm{O}_{2}$ optode probe (MultiLine ${ }^{\circledR}$ IDS 3430, WTW GmbH, Weilheim, Germany, accuracy: $\pm 0.5 \%$ of measured value). Specimen BNF was quantified using an adapted acetylene $\left(\mathrm{C}_{2} \mathrm{H}_{2}\right)$ reduction assay (Wilson and others 2012) during a full dark-light cycle incubation $(24 \mathrm{~h})$. Gas samples were collected from each chamber at time intervals and ethylene $\left(\mathrm{C}_{2} \mathrm{H}_{4}\right)$ concentrations were measured using a customized reducing compound photometer (RCP) (Peak Laboratories, detection limit $=100 \mathrm{ppb}$ ). $\mathrm{O}_{2}$ and $\mathrm{C}_{2} \mathrm{H}_{4}$ fluxes of the biological samples were corrected for unfiltered seawater control signals and normalized to incubation time and specimen 3D surface area. Unfiltered seawater signal was also recorded and normalized to per liter water volume.

\section{Data Treatment}

$\mathrm{O}_{2}$ and $\mathrm{C}_{2} \mathrm{H}_{4}$ fluxes were converted into $\mathrm{C}$ and $\mathrm{N}$ fluxes assuming theoretical molar ratios of
$\mathrm{CO}_{2}: \mathrm{O}_{2}=1$ and $\mathrm{C}_{2} \mathrm{H}_{4}: \mathrm{N}_{2}=4$. While we acknowledge that these ratios may vary depending on the biological system under study (Larkum 1988; Larkum and others 1988; Falkowski and Raven 2007), many systems display ratios not substantially different from these theoretical ratios (Capone 1988; Clavier and others 1994), and the use of the conservative theoretical ratios does allow here to compare GPP and BNF rates by different reef organisms. To estimate GPP, each specimen R measurement was added to its corresponding NPP measurement. NPP and GPP were extrapolated to per day estimates assuming $12 \mathrm{~h}$ of daylight, whereas daily R and BNF were calculated on a $24-\mathrm{h}$ diel cycle. Daily $\mathrm{C}$ and $\mathrm{N}$ fluxes obtained for each benthic category were then normalized to the reef benthos $3 \mathrm{D}$ area considering the respective $2 \mathrm{D}: 3 \mathrm{D}$ conversion factor and are reported in Table S4 expressed as mmol (C or N) $\mathrm{m}^{-2}$ benthos $3 \mathrm{D}$ area $\mathrm{d}^{-1}$. These represent fluxes of $\mathrm{C}$ and $\mathrm{N}$ from (or to) a square meter of reef benthos entirely composed by the respective category. Category-specific rates were then used to calculate the contribution of each benthic category to total benthic GPP, NPP, and BNF taking into account its relative $2 \mathrm{D}$ benthic cover in each reef habitat and season (Figure S1, Table S1, S2). Note that the physiological rates used here were measured under the average light intensity (10 m water depth) and may not capture the full depth-related profile of GPP and BNF on the reef. Consequently, our calculation only approximates the relative contribution of each reef habitat to reef-wide GPP and BNF. Nonetheless, it does provide a solid basis for assessing the overall significance and range of GPP and BNF that may occur at the reef ecosystem level. To allow comparison with other benthic systems, resulting contributions in mmol ( $\mathrm{C}$ or $\mathrm{N}) \mathrm{d}^{-1}$ were subsequently normalized to the reef planar 2D area and are expressed as mmol (C or N) $\mathrm{m}^{-2}$ planar $2 \mathrm{D}$ area $\mathrm{d}^{-1}$. To calculate the contribution of the water column to the reef ecosystem, GPP and BNF rates in nmol (C or N) $\mathrm{m}^{-3} \mathrm{~d}^{-1}$ (based on incubations of unfiltered seawater, Table S3) were extrapolated to the volume of the total reef area (Table S2) assuming relatively constant planktonic GPP and BNF in the surface mixed layer as it was previously observed in the Gulf of Aqaba (Foster and others 2009; Rahav and others 2015). We used the equations for the propagation of random errors (Miller and Miller 2005) to calculate uncertainties in the budget stepby-step calculations. The percentage of new production potentially achieved throughout $\mathrm{N}_{2}$ fixation, as opposite to regenerated production that is supported by recycling of nutrients (Dugdale and 
Goering 1967), was estimated using the percentage contribution of BNF to NPP, assuming a C:N ratio of 550:30 to estimate the demand of $\mathrm{N}$ for biomass generation of reef benthic autotrophs (Atkinson and Smith 1983; Atkinson and Falter 2003).

\section{Statistical Analysis}

Analyses were conducted using Primer-E v6 (Clarke and Gorley 2006) with the PERMANOVA extension (Anderson and others 2008). Differences in the benthic community cover among seasons (fixed, four levels) and reef habitats (fixed, five levels) were tested for significance using multivariate analysis of variance (PERMANOVA) on a Bray-Curtis similarity matrix of square-root transformed data. Type I (sequential) sum of squares was used with permutation of residuals under a reduced model (9999 permutations). Differences among habitats were visualized using principal coordinate analysis (PCO). Vector plots using Pearson ranking based on correlations greater than 0.4 were overlaid on the PCO plot to visualize relationships between variables and the ordination axes. Canonical analysis of principal coordinates (CAP, Anderson and others 2008) was used to identify specific groups in the benthic community responsible for differences among seasons, and benthic categories with correlations greater than 0.4 were overlaid on the plot as vectors. Differences in BNF, GPP, and R among seasons (four levels) were tested for significance using PERMANOVA on a Bray-Curtis similarity matrix of square-root transformed data. Type I (sequential) sum of squares was used with unrestricted permutation of raw data (9999 permutations). If data did not conform to assumptions of homogeneity after transformation, tested with PERMDISP (Anderson and others 2008), a conservative $\alpha$ value of 0.01 was used (Underwood 1997). Differences among seasons were visualized using PCOs, with benthic categories correlation vectors overlaid on the plots.

\section{Results}

\section{Seasonal Environmental Conditions}

Seawater temperature was stable around $22^{\circ} \mathrm{C}$ throughout winter and spring, but increased to $27^{\circ} \mathrm{C}$ in summer and decreased again in autumn (Table 1). Daily light availability increased from winter to spring and summer, and then decreased towards autumn. Inorganic nutrient and $\mathrm{Chl} a$ concentrations were significantly lower in summer and autumn than in winter and spring. Conversely, DOC showed higher concentrations in summer and autumn. POC concentrations did not differ between the seasons, while PN was lower in summer and autumn, with subsequent increase of the POC:PN ratio. Planktonic BNF was highly variable within seasons, with no significant seasonal differences, while planktonic GPP was significantly lower in summer and autumn compared to winter and spring (Table 1). Overall, the stratified season resembled warm and highly oligotrophic conditions, typical of tropical coral reefs worldwide, whereas the mixed season showed environmental conditions that are typical of marginal reef communities (Table 1, Kleypas and others 1999).

Table 1. Environmental Conditions during the Four Different Seasons at the Study Site (10 m water depth), and Comparison with Typical Values for Tropical Oligotrophic Waters as Reported by (a) Kleypas and others (1999); (b) Atkinson and Falter (2003); (c) Großkopf and others (2012); and (d) Torréton and others (2010)

\begin{tabular}{lccccc}
\hline Parameter & Winter & Spring & Summer & Autumn & Typical conditions \\
\hline Temperature $\left({ }^{\circ} \mathrm{C}\right)$ & $22.3(0.1)$ & $22.4(0.1)$ & $27.0(0.2)$ & $24.9(0.1)$ & $27.6(1.1)^{\mathrm{a}}$ \\
Light $\left(\mathrm{mol}\right.$ quanta $\left.{ }^{-2} \mathrm{~d}^{-1}\right)$ & $3.45(0.26)$ & $5.76(0.13)$ & $6.99(0.32)$ & $3.80(0.34)$ & - \\
DIN $(\mu \mathrm{M})$ & $1.25(0.13)$ & $1.11(0.07)$ & $0.31(0.06)$ & $0.47(0.09)$ & $(0.1-1.1)^{\mathrm{b}}$ \\
DIP $(\mu \mathrm{M})$ & $0.11(0.01)$ & $0.10(0.01)$ & $0.04(0.01)$ & $0.04(0.01)$ & $(0.05-0.3)^{\mathrm{b}}$ \\
Chl $a\left(\mu \mathrm{g} \mathrm{L}{ }^{-1}\right)$ & $0.21(0.01)$ & $0.20(0.02)$ & $0.10(0.00)$ & $0.19(0.02)$ & - \\
DOC $(\mu \mathrm{M})$ & $76.62(3.82)$ & $73.07(3.13)$ & $88.60(1.93)$ & $85.15(1.46)$ & $\sim 100^{\mathrm{b}}$ \\
POC $(\mu \mathrm{M})$ & $5.90(0.56)$ & $9.47(1.39)$ & $7.62(1.01)$ & $8.86(0.38)$ & $\sim 10^{\mathrm{b}}$ \\
PN $(\mu \mathrm{M})$ & $0.94(0.05)$ & $1.18(0.14)$ & $0.92(0.11)$ & $0.90(0.04)$ & $<1.0^{\mathrm{b}}$ \\
POC:PN & $6.81(0.59)$ & $7.95(0.47)$ & $8.25(0.34)$ & $9.86(0.45)$ & - \\
BNF $\left.(\mathrm{nmol} \mathrm{N} \mathrm{L})^{-1} \mathrm{~d}^{-1}\right)$ & $3.1(4.8)$ & $3.3(5.6)$ & $8.1(9.2)$ & $2.6(4.0)$ & $2.5(0.0-12.4)^{\mathrm{c}}$ \\
GPP $\left(\mu \mathrm{mol} \mathrm{C} \mathrm{L} \mathrm{d}^{-1}\right)$ & $1.0(0.4)$ & $1.1(0.7)$ & $0.4(0.8)$ & $0.6(0.2)$ & $0.5(0.1)^{\mathrm{d}}$
\end{tabular}

Planktonic $\mathrm{N}_{2}$ fixation rates are compared with BNF rates $\left({ }^{15} \mathrm{~N}\right.$ dissolution method) obtained by Großkopf and others (2012) for oligotrophic ocean waters, while values from Torréton and others (2010) are considered representative of GPP $\left({ }^{14} \mathrm{C}\right.$-method) in coral reef waters isolated from terrestrial influence. Values are means with SD or range of values in parentheses. 


\section{Benthic Community Composition}

Analysis of LPI data yielded the percentage coverage by all benthic categories as reported in Table S1. Multivariate analysis of the benthic community (Table S5) showed a significant effect of the factors 'Season' and 'Reef Habitat' (PERMANOVA: $P<0.001$ ), but not of their interaction (PERMANOVA: $P>0.1$ ). Distinctive communities (Figure 2) characterized the different reef habitats. The reef flat was correlated with coral rock, turf algae on rock, CCA, and zoanthids. The reef crest was dominated by coral rock, Millepora, turf algae on rock, and CCA. Conversely, the sand belt was correlated with 'bare' sediment, coral rubble, and turf algae on sediment, whereas hard and soft corals dominated the fore reef. The transition zone harbored an intermediate community between the sand belt and the fore reef, correlated with the presence of sponges, sediments, and microbial mats on sediment, but also hard and soft corals (Figure 2). Differences among seasons were not visible using the unconstrained ordination of the PCO technique. However, the CAP analysis revealed that seasonal changes were mainly attributable to macroalgae, microbial mats, and turf algae cover (Figure S1) that were higher in winter and spring (turf algae), only in spring (macroalgae and microbial mats on rock), or in spring and summer (microbial mats on sediment).

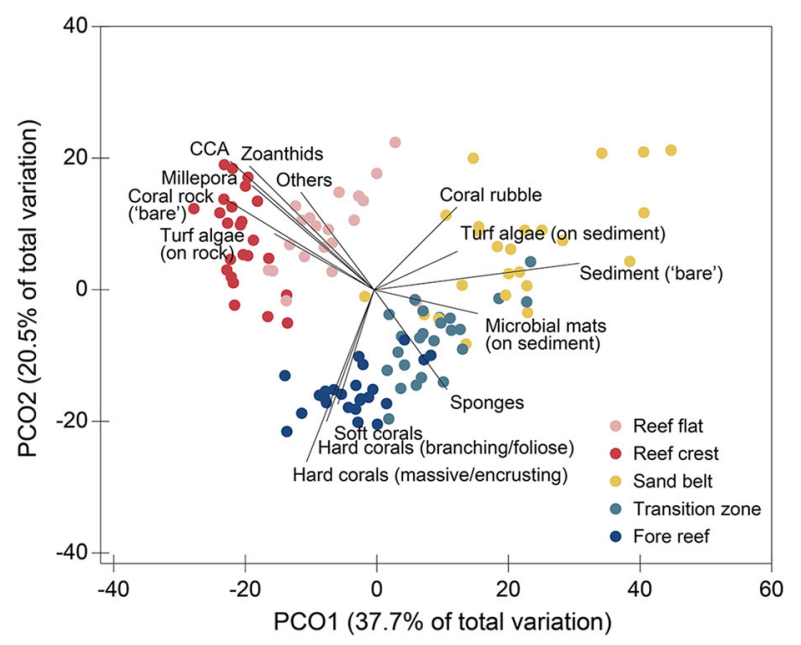

Figure 2. Principle coordinate analysis (PCO) of benthic community cover at the different reef habitats. Different colors represent different habitats as in the habitat map in Fig. 1. Vector overlay represents correlations greater than 0.4 based on Pearson ranking.

\section{Metabolic Rates of Individual Benthic Categories}

Benthic community metabolic rates showed significant differences between seasons (PERMANOVA: $P<0.001$ and pair-wise comparisons, Table S6). GPP displayed a weak seasonal pattern, but generally increased in spring and summer compared to the other seasons for all benthic primary producers (Figure S2a). Hard corals, soft corals, microbial mats, and turf algae on rock displayed the highest rates of benthos 3D area-related GPP, whereas sediment showed the lowest rates (Table S4). R increased in summer for all benthic categories except for macroalgae and sediment that displayed higher $\mathrm{R}$ in spring compared to the other seasons (Figure S2b). The highest benthos 3D arearelated $\mathrm{R}$ rates were associated with sponges and hard and soft corals, the lowest with sediment (Table S4). Compared to GPP and R, individual BNF rates showed a more pronounced seasonal pattern, with highest rates recorded in summer compared to all other seasons, except for sand-associated categories (macroalgae, sediment, and microbial mats) that showed the highest BNF in spring compared to the other seasons (Figure S2c). The highest benthos $3 \mathrm{D}$ area-related BNF rates were found for microbial mats on rock, the lowest for soft corals and sponges (Table S4).

\section{Contribution of the Different Benthic Categories to Reef GPP and BNF}

Hard corals contributed the largest share to benthic GPP (41-76\%) over all seasons and in all reef habitats (Figure 3A), even in the sand belt where their benthic cover was less than $20 \%$ (Table S1). Soft corals contributed importantly to GPP in the fore reef $(8-11 \%)$, in the transition zone (13$20 \%)$, and on the reef flat $(7-16 \%)$, but their contribution was low in other reef habitats. The contribution of 'bare' sediment to GPP was only relevant in the sand belt (4-20\%). 'Bare' hard substrates (that is, 'bare' coral rock and dead corals, see Table S3) contributed importantly to GPP in shallow and sandy reef habitats (that is, reef flat, reef crest, sand belt) in winter, summer, and autumn (11-26\%), but their contribution was low in spring $(5-8 \%)$ as a result of lower GPP rates (Figure S2, Table S4) and lower benthic coverage (Table S1). Turf algae provided a larger share of benthic GPP in shallow reef habitats (that is, reef flat, reef crest) in winter and spring (9-20\%), but less in summer and autumn. Turf algae also contributed importantly in winter in the sand belt 

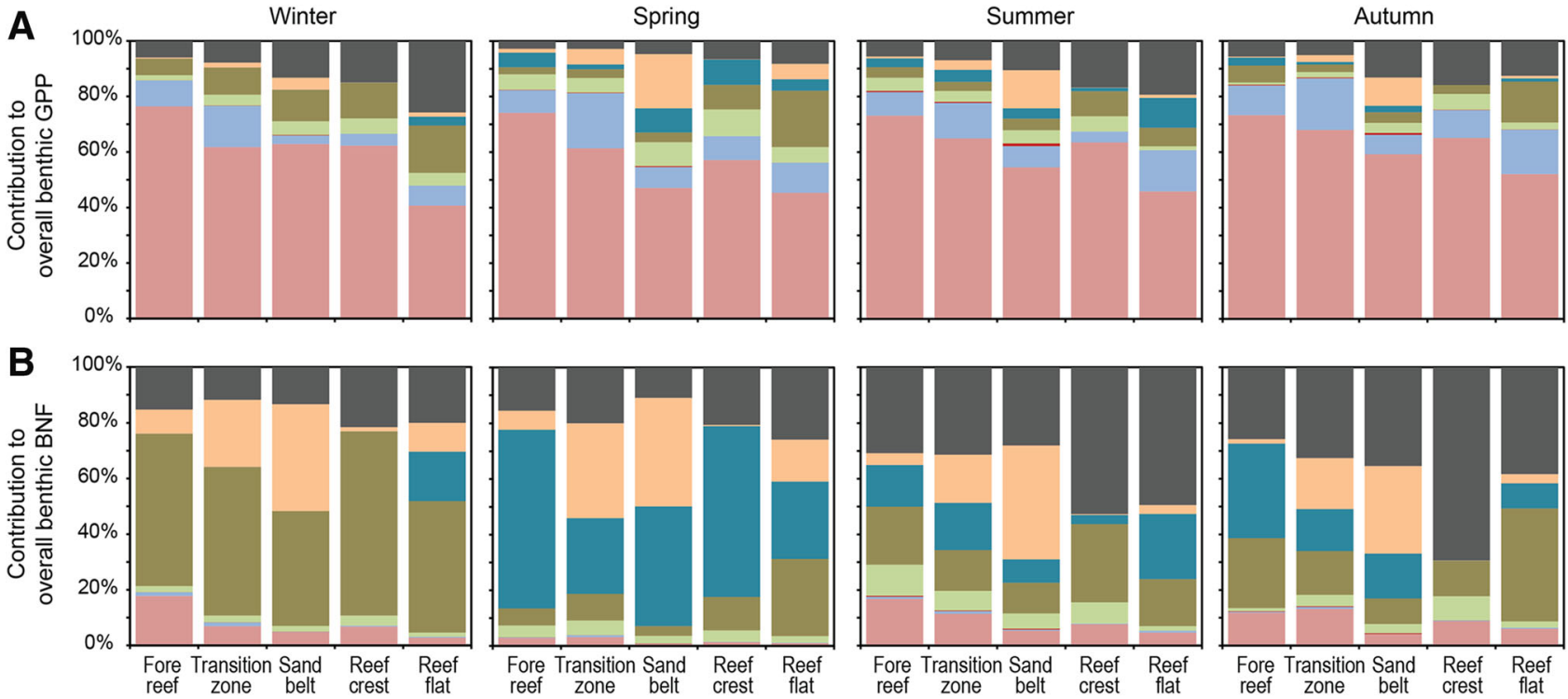

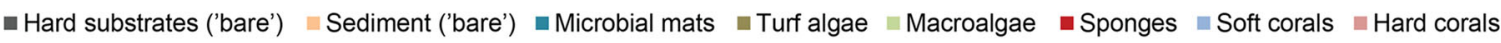

Figure 3. Contribution of the main benthic components to GPP (A) and BNF (B) for the four seasons and for each reef habitat. All hard coral morphologies are classified as one category; coral rock and dead corals are grouped into hard substrates ('bare'); macroalgae, microbial mats, and turf algae include categories 'on rock' and 'on sediment'.

Table 2. Community Dinitrogen Fixation (BNF), Gross Primary Production (GPP), Respiration (R), Net Primary Production (NPP) in mmol (C or N) $\mathrm{m}^{-2}$ Planar 2D Area $\mathrm{d}^{-1}$, and \% Contribution of BNF to NPP in the Different Reef Habitats

\begin{tabular}{lllllll}
\hline Habitat & $\begin{array}{l}\text { BNF (Larkum and } \\
\text { others 1988) }\end{array}$ & BNF & GPP & R & NPP & \% contribution \\
\hline Water column & - & $0.03(0.02-0.06)$ & $5(3-7)$ & $46(30-55)$ & - & \\
Reef flat & $(0.67-1.33)$ & $0.62(0.22-1.18)$ & $205(178-240)$ & $109(86-145)$ & $96(88-112)$ & $11.7(4.4-22.9)$ \\
Reef crest & $(0.05-0.11)$ & $0.61(0.15-1.07)$ & $246(222-266)$ & $137(121-165)$ & $109(88-139)$ & $10.0(2.6-19.2)$ \\
Sand belt & $(0.02-0.04)$ & $0.49(0.14-0.83)$ & $149(117-173)$ & $85(75-97)$ & $65(42-95)$ & $13.7(4.0-23.8)$ \\
Transition zone & - & $0.41(0.14-0.80)$ & $268(234-303)$ & $154(134-186)$ & $114(95-156)$ & $6.7(2.6-14.2)$ \\
Fore reef & $(0.18-0.40)$ & $0.50(0.10-0.78)$ & $327(284-359)$ & $190(167-223)$ & $137(116-187)$ & $6.6(1.6-12.0)$
\end{tabular}

Values are means followed by the range in parentheses.

(11\%), because of their high benthic coverage (Table S1). Macroalgae were unimportant to overall reef GPP, although their contribution was higher in shallow and sandy reef habitats in spring $(6-10 \%)$ than in other seasons. Microbial mats contributed minor fractions to reef GPP, but their contribution was variable and sometimes important, depending on their benthic coverage and increasing up to $11 \%$ on the reef flat in summer (Figure 3A). Conversely, sponges showed negligible contributions to benthic GPP in all reef habitats and over all seasons.
Benthic categories contributing most to BNF were microbial mats, turf algae, 'bare' hard substrates, and 'bare' sediment (Figure 3B). Despite very low benthic coverage $(0-1.7 \%)$ microbial mats provided a large fraction of BNF in spring in all reef habitats $(27-64 \%)$, but their contribution to BNF was lower and variable in other seasons. Turf algae contributed the largest share of BNF in winter in all reef habitats $(41-66 \%)$, but were also important in other seasons, particularly in the reef crest and reef flat $(12-41 \%)$. 'Bare' hard substrates were important to BNF in all reef habitats and seasons (11- 


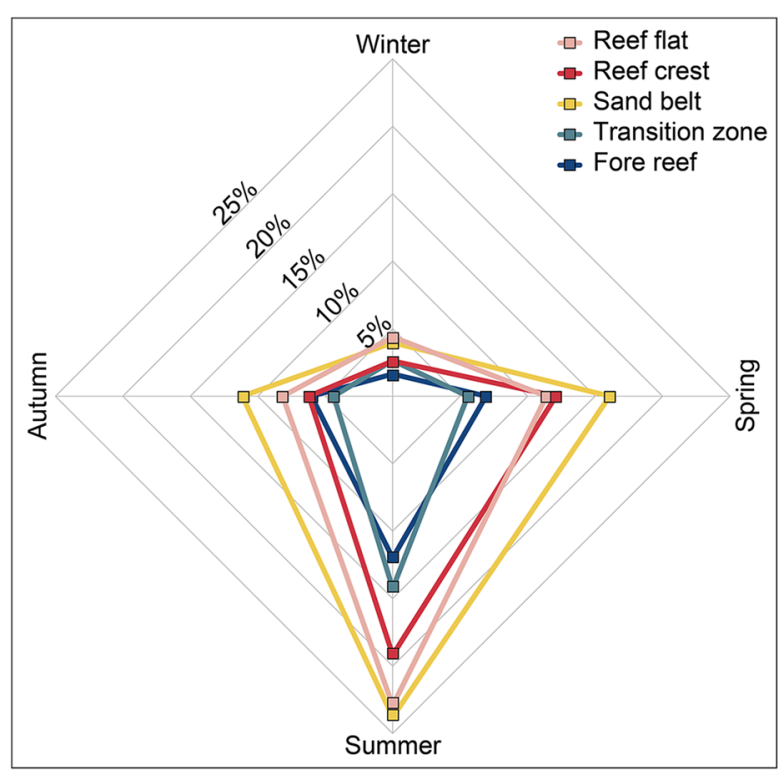

Figure 4. Contribution of BNF to NPP in all reef habitats and in all seasons. Different colors represent different habitats as in the habitat map in Fig. 1.

$69 \%$ ), particularly in summer and autumn in the reef crest and reef flat (38-69\%). 'Bare' sediment contributed a large fraction of BNF in the sand belt in all seasons (31-41\%), and was also important in the transition zone (17-34\%). The contribution of hard corals was low but occasionally relevant (for example, in the fore reef, with up to $18 \%$ in winter and $17 \%$ in summer). Macroalgae showed significant individual BNF rates (Table S4), but very low benthic coverage (Table S1), consequently contributing a low fraction of reef BNF (Figure 3B). Sponges and soft corals showed negligible contributions to BNF in all habitats in all seasons (Figure 3B).

\section{Areal GPP and BNF in the Different Reef Habitats}

Areal physiological rates of BNF and GPP in the water column were respectively approximately 20 and 60-fold lower compared to areal rates of the benthos (Table 2). However, areal planktonic $\mathrm{R}$ rates were only about 3-fold lower than benthic $\mathrm{R}$ rates, and the water column was net heterotrophic throughout the year (Table 2). Areal BNF rates were highest on the reef flat and lowest on the fore reef, whereas GPP and R were lowest on the sand belt. In general, reef habitats with the highest live coral cover (that is, reef crest, transition zone, and fore reef, Table S1) showed higher areal GPP and NPP (Table 2). BNF contributed significantly to NPP in all reef habitats (Table 2). However, its contri-
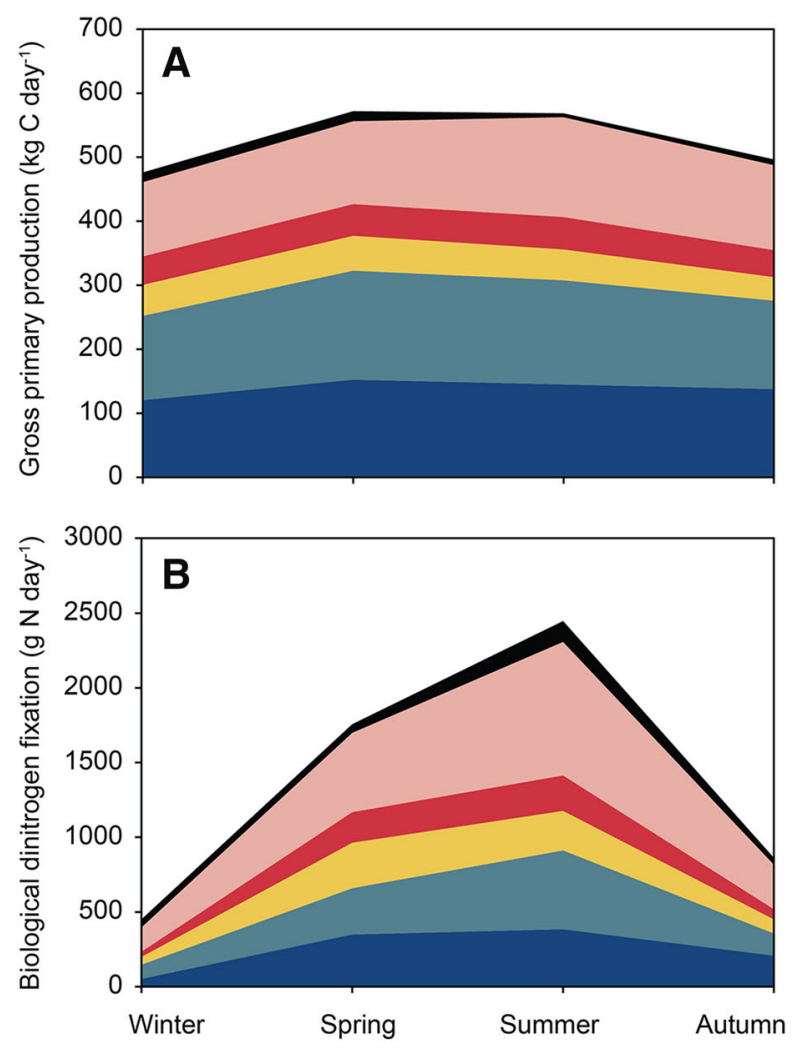

$\begin{array}{lll}\text { - Water column } & \text { Reef flat } & \text { Reef crest } \\ \text { Sand belt } & \text { Transition zone } & \text { Fore reef }\end{array}$

Figure 5. Contribution of each reef habitats to reef-wide GPP (A) and BNF (B) in the four seasons. Different colors represent different habitats as in the habitat map in Fig. 1, and black represents the contribution of the water column integrated for the entire reef water volume (see Table S2).

bution to NPP was highly seasonal, lowest in winter, and highest in summer in all reef habitats (Figure 4). The largest share of NPP was contributed by BNF in the sand belt, where NPP was lowest (Table 2; Figure 4), whereas contribution of BNF to NPP was generally low in the transition zone and fore reef (Figure 4). On average, BNF contributed about $10 \%$ of reef NPP on a yearly basis, while its contribution was 2 -fold in summer (ca. 20\%).

\section{Reef-Wide GPP and BNF}

The different reef habitats and the water column contributed differently to total reef-wide GPP and BNF (Figure 5A, B). The substantial areal extent and live coral cover of the fore reef, transition zone, and reef flat determined their important contribution to reef-wide GPP. Conversely, the sand belt and the reef crest contributed a lower share of reef- 
wide GPP as these habitats show smaller areal extent (Figure 5A, Table S2). The contribution of the water column was always the lowest, and was insignificant for total reef-wide GPP (Figure 5A). To a lesser extent, this was also true for reef-wide $\mathrm{BNF}$, where the contribution of the water column was comparable to that of benthic habitats only in winter (Figure 5B). Among benthic habitats, the reef flat contributed the largest share of reef-wide $\mathrm{BNF}$, whereas the reef crest contributed the smallest (Figure 5B). BNF in the sand belt was highest in spring, whereas BNF in all other reef habitats and in the water column was highest in summer (Figure 5B). Overall, although total reefwide GPP remained relatively stable year around (Figure 5B), total reef-wide BNF displayed a strong seasonal pattern with 4 -fold higher rates in spring and summer compared to winter and autumn (Figure $5 b$ ).

\section{Discussion}

Inputs of bioavailable $\mathrm{N}$, particularly from BNF, may play a key role in the health and resilience of coral reef ecosystems (Wooldridge 2009; Holmes and Johnstone 2010; D'Angelo and Wiedenmann 2014). Thus, a detailed budget of nutrient fluxes in coral reefs is urgently needed for developing successful management actions ( $\mathrm{D}^{\prime}$ Angelo and Wiedenmann 2014). This study extends early fundamental work (Wiebe and others 1975; Larkum and others 1988) by generating a seasonal BNF budget for a coral reef community based on individual rates of all dominant benthic substrates and the reef-overlying water column. To our knowledge, this is the first attempt to combine substrate-specific GPP, R, and BNF rates extrapolated to their respective benthic 3D surface areas and to quantify their magnitude at the reef ecosystem level. Quantitatively expressing the uncertainty originating from direct measurements and natural variability in ecological studies involving step-by-step calculations is also important. In fact, this can improve the interpretation of data and simplify the estimation of risk associated with the management of an ecosystem (Lehrter and Cebrian 2010). Hence, in the present budget we used the equations for the propagation of random errors (Miller and Miller 2005) to constrain areal physiological rates with an assessment of the propagated uncertainty. GPP, R, and BNF rates presented here for the individual substrates fall well within those from previous studies that reported similar measurements from other reef environments (for example, see values in Nau- mann and others 2013; Cardini and others 2014), and they appear robust against the associated propagated errors. However, there is considerable uncertainty in any such budget, and the increased complexity of the analyses introduced new sources of error in our budget. These include: (1) deviations from the theoretical $\mathrm{CO}_{2}: \mathrm{O}_{2}$ and $\mathrm{C}_{2} \mathrm{H}_{4}: \mathrm{N}_{2}$ ratios in different benthic communities; (2) spatial variations in metabolic activity associated with the same substrates caused by the effect of water depth (for example, light availability) on the measured processes; (3) changes of ecosystem stoichiometry or deviations from the theoretical C:N ratio over space and time. Nonetheless, some results are solid and are thus discussed in the following sections, answering our key questions.

(1) There was a clear decoupling between the substrates that contributed most to reef GPP and the ones that were important for reef BNF. This indicates that these two biogeochemical processes are uncoupled ecosystem functions where changes in the benthic community structure may differentially affect the availability of essential energy $(\mathrm{C})$ or nutrients $(\mathrm{N})$ at the ecosystem level. Hard corals were the key primary producers in all habitats and seasons, whereas categories such as turf algae, 'bare' hard substrates, and sediment were more important for reef BNF. This indicates that the latter substrates are also key constituents of a functioning coral reef as they provide important settlement space for diazotrophs (Wiebe and others 1975; Shashar and others 1994b; den Haan and others 2014; Rix and others 2015). Importantly, other reef organisms can provide either ecosystem functions, thanks to symbioses (for example, hard corals, Cardini and others 2015) or an inherent capability (for example, microbial mats, Charpy and others 2010). These benthic categories are fundamental to reef ecosystem GPP and BNF, with respective contributions strongly depending on their benthic coverage. For example, recently dead hard corals provide surfaces covered in organic detritus that can be hotspots of BNF. Fluxes of inorganic $\mathrm{N}$ following bleaching-induced mortality were estimated being sufficient to direct an affected ecosystem toward a phase shift from coral to algal dominance (Davey and others 2008; Holmes and Johnstone 2010).

(2) In oligotrophic coral reefs such as the one investigated here, BNF and GPP are principally benthos-related processes (Atkinson 2011). 
The entire water column above the reef contributed to BNF and GPP at rates per area that were approximately 20 -fold and 60 -fold lower, respectively, than those contributed by the benthos. The daily budget of GPP and R of the water column resulted in a negative metabolic balance in all seasons and in particular during the stratified summer period (van Hoytema and others 2016). This indicates net heterotrophy of the planktonic community. Similar conditions have been described for other reef planktonic communities, and it has been suggested that respiration of planktonic heterotrophs may be fueled by the supply of organic matter from the reef benthos (Naumann and others 2012a; Haas and others 2013). Additional evidence supporting net heterotrophy of the water column in the Gulf of Aqaba comes from a study that focused on the diazotrophic community and found a shift from mixed to predominantly heterotrophic diazotrophs in summer (Rahav and others 2015). In any case, the actual rates by which the reef biota can extract dissolved $\mathrm{N}$ from flowing seawater are physically constrained (Atkinson 2011). Conversely, BNF by benthos-associated prokaryotes has the potential to provide a source of $\mathrm{N}$ readily available to the reef benthos. This fixed $\mathrm{N}$ enters the food web through leakage of ammonium or dissolved organic $\mathrm{N}$ (DON), or by direct grazing, and can be assimilated in situ through processes that have limited or no interaction with the water column. On the benthos, reef habitats that are contiguous to the reef framework (that is, sand-dominated zones) contribute a large fraction of the newly fixed $\mathrm{N}$ to the reef ecosystem, as indicated by others (Capone and others 1992; Shashar and others 1994b; O'Neil and Capone 2008). However, the significance of the reef framework has previously been overlooked. In fact, these areas (for example, reef crest and fore reef) and the reef framework community in general, contribute newly fixed $\mathrm{N}$ at areal rates comparable if not higher than those of sand-dominated zones when accounting for their 3D surface area (Table 3). Moreover, our results confirm that high-coral cover habitats are unrivaled in terms of GPP, shaping coral reef ecosystem productivity, and growth.

(3) Despite the fact that the two processes of GPP and BNF appear to be provided by different benthic categories as uncoupled ecosystem functions, we did find a potentially strong biogeochemical link between the two at the ecosystem level. In fact, BNF could sustain approximately $10 \%$ of NPP of the entire reef system on an annual basis, and up to about $20 \%$ of NPP in summer when inorganic nutrient concentrations were lowest. These results are similar to previous studies at other reef locations (Charpy-Roubaud and others 2001; Charpy and others 2007; Casareto and others 2008; Charpy and others 2010) and show that reef ecosystems, particularly those that experience oligotrophic conditions, rely significantly on BNF as an internal source of $\mathrm{N}$ to sustain their high ecosystem productivity. Our findings however confirm that BNF can only sustain a portion of reef NPP. Future studies should focus on the potentially important role of external sources (for example, of oceanic origin) of DON that may also sustain new production and growth in coral reefs. In fact, the DON pool is made up of poorly characterized compounds to which little attention has been given (see Suzuki and Casareto 2011), although mass balance calculations have highlighted its importance for benthic and pelagic production in tropical coral reef environments characterized by low inorganic N (Eyre and others 2008).

(4) Reef-wide GPP was increased in spring and summer (mostly driven by higher respiration, see also van Hoytema and others 2016), but relatively stable over the year despite strong seasonal shifts in environmental conditions. Conversely, reef-wide BNF was more susceptible to seasonality, being 5 -fold higher in summer compared to winter. Several studies have shown that BNF is susceptible to changes in environmental factors such as temperature, nutrient concentrations, light, $\mathrm{pH}$, and $\mathrm{O}_{2}$, among others (see Carpenter and Capone (2008) and Cardini and others (2014) for syntheses). The present study further indicates that changes in BNF of single benthic categories have cascading effects at the reef ecosystem level. Moreover, although hard corals consistently showed the highest contribution to GPP in all habitats and seasons, substrates that mainly contributed to BNF changed from season to season, with turf algae contributing most in winter, microbial mats in spring, and 'bare' substrates in summer and autumn. Overall, these results suggest that climate exerts a strong control on BNF and that changes in benthic reef community composition drive strong feedbacks on the associated diazotrophic community and consequently on its provision of new $\mathrm{N}$ to the ecosystem. 
Table 3. Estimate of the Total Contribution of BNF to the $\mathrm{N}$ Cycle in Benthic Coral Reef Environments, Compared with Previous Studies

\begin{tabular}{|c|c|c|c|c|c|}
\hline Study location & Community & Time of year & $\begin{array}{l}\text { Temperature } \\
\left({ }^{\circ} \mathrm{C}\right)\end{array}$ & $\begin{array}{l}\text { Areal rate } \\
\left(\mu \mathrm{mol} \mathrm{N} \mathrm{m}{ }^{-2} \mathrm{~d}^{-1}\right)\end{array}$ & References \\
\hline Aqaba, Jordan & $\begin{array}{l}\text { Reef framework } \\
\text { community }\end{array}$ & Annual average & $(22.0-27.5)$ & $536(69)$ & This study \\
\hline Aqaba, Jordan & $\begin{array}{l}\text { Soft bottom } \\
\text { community }\end{array}$ & Annual average & $(22.0-27.5)$ & $488(62)$ & This study \\
\hline Aqaba, Jordan & $\begin{array}{l}\text { Reef framework } \\
\text { community }\end{array}$ & Summer & $27.0(0.2)$ & $956(151)$ & This study \\
\hline Aqaba, Jordan & $\begin{array}{l}\text { Soft bottom } \\
\text { community }\end{array}$ & Summer & $27.0(0.2)$ & $723(110)$ & This study \\
\hline One Tree Reef & Various substrates & Annual range & $(20-30)$ & $(156-1330)^{a}$ & Larkum and others (1988) \\
\hline Eilat, Israel & Various substrates & Summer & $\mathrm{n} / \mathrm{a}$ & $(1152-1968)^{a}$ & Shashar and others (1994b) \\
\hline
\end{tabular}

\section{Responses to Environmental Forcing}

Climatic controls on biogeochemical cycles are relevant in coral reefs because their biological activity is mainly driven by light intensity, water temperature, and nutrient availability. The fringing reef under study is exposed to seasonally changing environmental conditions. The stratified summer resembles typical conditions of tropical reef communities worldwide, which are characterized by warm and highly oligotrophic waters, whereas mixed season (winter) conditions are similar to marginal reef environments, where nutrient concentrations are often higher and temperature and light intensity are lower (Kleypas and others 1999). In the studied reef, BNF was highest in spring and summer, suggesting an important role of light availability, which showed a correlating seasonal pattern, as the main controlling environmental factor at the ecosystem level. The higher summer temperature $\left(27^{\circ} \mathrm{C}\right)$ also likely exerted an important control on BNF, as summer individual BNF rates were highest of all seasons. These results are consistent with previous studies that found BNF on coral reef substrates to be primarily light and temperature dependent (Wilkinson and others 1985; Larkum and others 1988). Conversely, the relatively high spring DIN concentrations $(>1 \mu \mathrm{M})$ did not cause a decrease of reef-wide BNF, suggesting that these concentrations were still low enough to prevent nitrogenase (that is, the enzyme responsible for BNF) inhibition (for example, Mulholland and others 2001). Moreover, BNF may still be a winning strategy in coral reef environments where energy sources are typically low in ammonium compared to carbon (that is, high $\mathrm{C}: \mathrm{N}$ ratio, see
Atkinson 2011) and thus it is where organisms benefit from additional bioavailable $\mathrm{N}$ even at relatively high DIN concentrations. At this point however, it is difficult to predict which environmental factors dominate and how their complex interactive effects influence BNF in reef ecosystems, calling for experiments where separate environmental factors are manipulated to disentangle the single responses (for example, see Koop and others 2001).

\section{Conclusions}

GPP and BNF are closely linked in the marine environment for two reasons. First, BNF is a primary source of bioavailable $\mathrm{N}$, which is a major component of chlorophyll, amino acids, energytransfer compounds, and nucleic acids. Second, BNF requires energy that is supplied directly (photosynthetic diazotrophs) or indirectly (nonphotosynthetic diazotrophs) by primary production. Thus, quantifying BNF is highly relevant for understanding the functioning of the marine environment. Here, we revised previous estimates of reef-wide BNF scaling physiological measurements for individual benthic categories to their 3D surface area and to the ecosystem level using a GIS analysis of the reef under study. No such detailed budget has been attempted to date for coral reef ecosystems. Whole-ecosystem measurements (for example, flow respirometry, eddy correlation) provide informative activity data on the entire community (Silverman and others 2007; Long and others 2013). However, there is not yet a wholeecosystem method for reliably quantifying BNF. Moreover, our approach allowed us to differentiate 
between the involved groups of organisms. At the same time, our whole-ecosystem estimates for GPP, $\mathrm{R}$, and BNF fall in the range of those found for similar communities at other reef locations using both similar and different approaches (Atkinson and Grigg 1984; Hatcher 1988; Larkum and others 1988; Shashar and others 1994b; Silverman and others 2007; Long and others 2013; Eidens and others 2014), confirming the validity of our method. In Table 3, we present different estimates based on annual averages and on summer measurements only, as the latter ones may more closely approximate the scale and significance of BNF in other tropical reef systems (see section "Responses to Environmental Forcing"). These estimates, particularly those based on summer measurements, are similar to those presented by Larkum and others (1988) and by Shashar and others (1994b). However, importantly, the propagated errors associated with our estimates are relatively low despite taking into account the natural variability of a highly dynamic reef system, and should thus approximate the range of conditions found in other reef systems quite well. Consequently, the constrained estimates presented here of an important and so far poorly quantified reef $\mathrm{N}$ source can prove useful for environmental managers planning or evaluating the effects of nutrient management actions on the ecosystem biogeochemical cycling (for example, Boynton and others 2008). However, global and local anthropogenic environmental changes are predicted to profoundly alter coral reef communities and a variety of related ecosystem functions in the future (Hughes and others 2003; Hoegh-Guldberg 2011). As yet, large uncertainties remain in the potential responses of reef $\mathrm{BNF}$ and GPP to environmental change, requiring further assessments. It is clear, however, that the tight biogeochemical link between reef BNF and the $\mathrm{C}$ cycle will determine feedback loops, where perturbations in BNF will have repercussions in the $\mathrm{C}$ cycle, and vice versa. Ultimately, BNF dynamics need to be accounted for when projecting the future of coral reef ecosystem productivity in response to climate change.

\section{ACKNOWLEDGMENTS}

Open access funding provided by University of Vienna. We thank F. A. Al-Horani, S. Helber, and the MSS scientists and staff for field-work assistance and logistical support, and R. A. Foster, S. Wilson, D. G. Capone, M. Birkicht, and D. Peterke for their help and advice with sample and data analysis. This work was funded by German Re- search Foundation (DFG) grant Wi 2677/6-1 to CW with support of the German Leibniz Association (WGL) and a PhD stipend from Evangelisches Studienwerk Villigst e.V. to VNB.

\section{OPEN ACCESS}

This article is distributed under the terms of the Creative Commons Attribution 4.0 International License (http://creativecommons.org/licenses/by/ 4.0/), which permits unrestricted use, distribution, and reproduction in any medium, provided you give appropriate credit to the original author(s) and the source, provide a link to the Creative Commons license, and indicate if changes were made.

\section{REFERENCES}

Anderson M, Gorley RN, Clarke RK. 2008. Permanova + for Primer: Guide to Software and Statistical Methods.

Atkinson M, Grigg R. 1984. Model of a coral reef ecosystem. Coral Reefs 3:13-22.

Atkinson M, Smith S. 1983. C:N: P ratios of benthic marine plants. Limnol Oceanogr 28:568-74.

Atkinson MJ. 2011. Biogeochemistry of nutrients. In: Dubinsky Z, Stambler N, Eds. Coral reefs: an ecosystem in transition. Netherlands: Springer. p 199-206.

Atkinson MJ, Falter JL. 2003. Coral reefs. In: Black K, Shimmield G, Eds. Biogeochemistry of marine systems. Boca Raton: CRC Press. p 40-64.

Bednarz VN, Cardini U, van Hoytema N, Al-Rshaidat MMD, Wild C. 2015a. Seasonal variation in dinitrogen fixation and oxygen fluxes associated with two dominant zooxanthellate soft corals from the northern Red Sea. Mar Ecol Prog Ser 519:141-52.

Bednarz VN, van Hoytema N, Cardini U, Naumann MS, AlRshaidat MMD, Wild C. 2015b. Dinitrogen fixation and primary productivity by carbonate and silicate reef sand communities of the Northern Red Sea. Mar Ecol Prog Ser 527:47-57.

Boynton WR, Hagy JD, Cornwell JC, Kemp WM, Greene SM, Owens MS, Baker JE, Larsen RK. 2008. Nutrient Budgets and Management Actions in the Patuxent River Estuary, Maryland. Estuar Coasts 31:623-51.

Capone DG. 1988. Benthic Nitrogen Fixation. Blackburn TH, Sörensen J editors. Nitrogen cycling in coastal marine environments. New York: Published on behalf of the Scientific Committee on Problems of the Environment (SCOPE) of the International Council of Scientific Unions (ICSU) by Wiley, pp 85-123.

Capone DG (1996) Coral reef ecosystems in the context of the marine nitrogen cycle. In: Bjork M, Semesi AK, Pederson M, Bergman B, Eds. Current trends in marine botanical research in the east african region. Uppsala: SIDA, Marine Science Program, SAREC, pp 61-76.

Capone DG, Carpenter EJ. 1982. Nitrogen Fixation in the Marine Environment. Science 217:1140-2.

Capone DG, Dunham SE, Horrigan SG, Duguay LE. 1992. Microbial nitrogen transformations in unconsolidated coralreef sediments. Mar Ecol Prog Ser 80:75-88.

Cardini U, Bednarz VN, Foster RA, Wild C. 2014. Benthic $\mathrm{N}_{2}$ fixation in coral reefs and the potential effects of human-induced environmental change. Ecol Evolut 4:1706-27. 
Cardini U, Bednarz VN, Naumann MS, van Hoytema N, Rix L, Foster RA, Al-Rshaidat MMD, Wild C. 2015. Functional significance of dinitrogen fixation in sustaining coral productivity under oligotrophic conditions. Proc R Soc Lond B Biol Sci 282:20152257.

Carlson DF, Fredj E, Gildor H. 2014. The annual cycle of vertical mixing and restratification in the Northern Gulf of Eilat/ Aqaba (Red Sea) based on high temporal and vertical resolution observations. Deep Sea Research Part I: Oceanographic Research Papers 84:1-17.

Carpenter EJ, Capone DG. 2008. Nitrogen Fixation in the Marine Environment. Capone DG, Bronk DA, Mulholland MR, Carpenter EJ, Eds. Nitrogen in the marine environment (2nd edn). San Diego: Academic Press, pp 141-198.

Casareto B, Charpy L, Langlade M, Suzuki T, Ohba H, Niraula M, Suzuki Y. 2008. Nitrogen fixation in coral reef environments. Proceedings of the 11th International Coral Reef Symposium, pp 896-900.

Charpy-Roubaud C, Charpy L, Larkum AWD. 2001. Atmospheric dinitrogen fixation by benthic communities of Tikehau Lagoon (Tuamotu Archipelago, French Polynesia) and its contribution to benthic primary production. Mar Biol 139:991-7.

Charpy L, Alliod R, Rodier M, Golubic S. 2007. Benthic nitrogen fixation in the SW New Caledonia lagoon. Aquat Microb Ecol 47:73-81.

Charpy L, Palinska KA, Casareto B, Langlade MJ, Suzuki Y, Abed RMM, Golubic S. 2010. Dinitrogen-fixing cyanobacteria in microbial mats of two shallow coral reef ecosystems. Microb Ecol 59:174-86.

Clarke KR, Gorley RN. 2006. PRIMER v6. Plymouth, UK: Plymouth Marine Laboratory.

Clavier J, Boucher G, Garrigue C. 1994. Benthic respiratory and photosynthetic quotients in a tropical lagoon. Comptes Rendus de l'Académie des Sciences. Série 3: Sciences de la Vie 317: 937-942.

Cuet P, Atkinson MJ, Blanchot J, Casareto BE, Cordier E, Falter J, Frouin P, Fujimura H, Pierret C, Susuki Y, Tourrand C. 2011. CNP budgets of a coral-dominated fringing reef at La Réunion, France: coupling of oceanic phosphate and groundwater nitrate. Coral Reefs 30:45-55.

D'Elia CF, Wiebe WJ. 1990. Biogeochemical nutrient cycles in coral-reef ecosystems. In: Dubinsky Z, Ed. Coral Reefs. Amsterdam: Elsevier, pp 49-74.

D'Angelo C, Wiedenmann J. 2014. Impacts of nutrient enrichment on coral reefs: new perspectives and implications for coastal management and reef survival. Curr Opin Environ Sustain 7:82-93.

Davey M, Holmes G, Johnstone R. 2008. High rates of nitrogen fixation (acetylene reduction) on coral skeletons following bleaching mortality. Coral Reefs 27:227-36.

den Haan J, Visser P, Ganase A, Gooren E, Stal L, van Duyl F, Vermeij MA, Huisman J. 2014. Nitrogen fixation rates in algal turf communities of a degraded versus less degraded coral reef. Coral Reefs 33:1003-15.

Dugdale RC, Goering JJ. 1967. Uptake of new and regenerated forms of nitrogen in primary productivity. Limnol Oceanogr $12: 196-206$

Eidens C, Bayraktarov E, Hauffe T, Pizarro V, Wilke T, Wild C. 2014. Benthic primary production in an upwelling-influenced coral reef, Colombian Caribbean. PeerJ 2:e554.
Eyre BD, Glud RN, Patten N. 2008. Mass coral spawning: A natural large-scale nutrient addition experiment. Limnol Oceanogr 53:997-1013.

Falkowski PG, Raven JA. 2007. Aquatic photosynthesis (2nd edn). Princeton University Press.

Fiore CL, Jarett JK, Olson ND, Lesser MP. 2010. Nitrogen fixation and nitrogen transformations in marine symbioses. Trends Microbiol 18:455-63.

Foster RA, Paytan A, Zehr JP. 2009. Seasonality of $\mathrm{N}_{2}$ fixation and nifH gene diversity in the Gulf of Aqaba (Red Sea). Limnol Oceanogr 54:219-33.

Geider R, La Roche J. 2002. Redfield revisited: variability of C:N: $\mathrm{P}$ in marine microalgae and its biochemical basis. Eur $\mathrm{J}$ Phycol 37:1-17.

Großkopf T, Mohr W, Baustian T, Schunck H, Gill D, Kuypers MMM, Lavik G, Schmitz RA, Wallace DWR, LaRoche J. 2012 Doubling of marine dinitrogen-fixation rates based on direct measurements. Nature 488:361-4.

Gruber N, Galloway JN. 2008. An Earth-system perspective of the global nitrogen cycle. Nature 451:293-6.

Haas AF, Naumann MS, Struck U, Mayr C, el-Zibdah M, Wild C. 2010. Organic matter release by coral reef associated benthic algae in the Northern Red Sea. J Exp Mar Biol Ecol 389:53-60.

Haas AF, Nelson CE, Rohwer F, Wegley-Kelly L, Quistad SD, Carlson CA, Leichter JJ, Hatay M, Smith JE. 2013. Influence of coral and algal exudates on microbially mediated reef metabolism. PeerJ 1:e108.

Hatcher BG. 1988. Coral reef primary productivity: A beggar's banquet. Trends Ecol Evolut 3:106-11.

Hoegh-Guldberg O. 2011. Coral reef ecosystems and anthropogenic climate change. Reg Environ Chang 11:215-27.

Holmes G, Johnstone RW. 2010. The role of coral mortality in nitrogen dynamics on coral reefs. J Exp Mar Biol Ecol 387:1-8.

Hughes TP, Baird AH, Bellwood DR, Card M, Connolly SR, Folke C, Grosberg R, Hoegh-Guldberg O, Jackson JBC, Kleypas J, Lough JM, Marshall P, Nyström M, Palumbi SR, Pandolfi JM, Rosen B, Roughgarden J. 2003. Climate change, human impacts, and the resilience of coral reefs. Science 301:929-33.

Kleypas JA, McManus JW, Meñez LAB. 1999. Environmental limits to coral reef development: where do we draw the line? Am Zool 39:146-59.

Koop K, Booth D, Broadbent A, Brodie J, Bucher D, Capone D, Coll J, Dennison W, Erdmann M, Harrison P, Hoegh-Guldberg $\mathrm{O}$, Hutchings $\mathrm{P}$, Jones GB, Larkum AWD, O'Neil J, Steven A, Tentori E, Ward S, Williamson J, Yellowlees D. 2001. ENCORE: the effect of nutrient enrichment on coral reefs. Synthesis of results and conclusions. Mar Pollut Bull 42:91-120.

Larkum AWD. 1988. High rates of nitrogen fixation on coral skeletons after predation by the crown of thorns starfish Acanthaster planci. Mar Biol 97:503-6.

Larkum AWD, Kennedy IR, Muller WJ. 1988. Nitrogen fixation on a coral reef. Mar Biol 98:143-55.

Lehrter JC, Cebrian J. 2010. Uncertainty propagation in an ecosystem nutrient budget. Ecol Appl 20:508-24.

Lesser MP, Mazel CH, Gorbunov MY, Falkowski PG. 2004. Discovery of symbiotic nitrogen-fixing cyanobacteria in corals. Science 305:997-1000.

Long MH, Berg P, de Beer D, Zieman JC. 2013. In situ coral reef oxygen metabolism: an eddy correlation study. PLoS ONE 8:e58581. 
Mergner H, Schuhmacher H. 1974. Morphologie, Ökologie und Zonierung von Korallenriffen bei Aqaba, (Golf von Aqaba, Rotes Meer). Helgolander Wissenschaftliche Meeresuntersuchungen 26:238-358.

Miller JN, Miller JC. 2005. Statistics and chemometrics for analytical chemistry. Harlow, England: Pearson Education Limited.

Mulholland MR, Ohki K, Capone DG. 2001. Nutrient controls on nitrogen uptake and metabolism by natural populations and cultures of Trichodesmium (Cyanobacteria). J Phycol 37:1001-9.

Naumann M, Haas A, Jantzen C, Iglesias-Prieto R, Wild C. 2012a. Benthic-pelagic coupling in a Caribbean reef lagoon affected by hurricane "Dolly". In: Proceedings of the 12th international coral reef symposium, p 12.

Naumann MS, Jantzen C, Haas AF, Iglesias-Prieto R, Wild C. 2013. Benthic Primary Production Budget of a Caribbean Reef Lagoon (Puerto Morelos, Mexico). PLoS ONE 8:e82923.

Naumann MS, Niggl W, Laforsch C, Glaser C, Wild C. 2009. Coral surface area quantification-evaluation of established techniques by comparison with computer tomography. Coral Reefs 28:109-17.

Naumann MS, Richter C, Mott C, el-Zibdah M, Manasrah R, Wild C. 2012b. Budget of coral-derived organic carbon in a fringing coral reef of the Gulf of Aqaba, Red Sea. J Mar Syst 105-108:20-29.

O'Neil JM, Capone D. 1989. Nitrogenase activity in tropical carbonate marine sediments. Mar Ecol Progr Ser 56:145-56.

O'Neil JM, Capone DG. 2008. Nitrogen Cycling in Coral Reef Environments. In: Capone DG, Bronk DA, Mulholland MR, Carpenter EJ, Eds. Nitrogen in the marine environment (2nd edn). San Diego: Academic Press, pp 949-989.

Rahav E, Herut B, Mulholland MR, Belkin N, Elifantz H, Berman-Frank I. 2015. Heterotrophic and autotrophic contribution to dinitrogen fixation in the Gulf of Aqaba. Mar Ecol Progr Ser 522:67-77.

Rix L, Bednarz VN, Cardini U, van Hoytema N, Al-Horani FA, Wild C, Naumann MS. 2015. Seasonality in dinitrogen fixation and primary productivity by coral reef framework substrates from the northern Red Sea. Mar Ecol Progr Ser . doi:10. 3354/mepsl 1383.
Schneider CA, Rasband WS, Eliceiri KW. 2012. NIH Image to ImageJ: 25 years of image analysis. Nat Methods 9:671-5.

Shashar N, Cohen Y, Loya Y, Sar N. 1994a. Nitrogen-fixation (acetylene reduction) in stony corals-evidence for coralbacteria interactions. Mar Ecol Progr Ser 111:259-64.

Shashar N, Feldstein T, Cohen Y, Loya Y. 1994b. Nitrogen-fixation (acetylene reduction) on a coral reef. Coral Reefs 13:171-4.

Silverman J, Lazar B, Erez J. 2007. Community metabolism of a coral reef exposed to naturally varying dissolved inorganic nutrient loads. Biogeochemistry 84:67-82.

Suzuki Y, Casareto B. 2011. The Role of dissolved organic nitrogen (DON) in coral biology and reef ecology. In: Dubinsky Z, Stambler N, Eds. Coral reefs: an ecosystem in transition. Netherlands: Springer. pp 207-14.

Torréton J-P, Rochelle-Newall E, Pringault O, Jacquet S, Faure V, Briand E. 2010. Variability of primary and bacterial production in a coral reef lagoon (New Caledonia). Mar Pollut Bull 61:335-48

Underwood AJ. 1997. Experiments in ecology: their logical design and interpretation using analysis of variance. Cambridge: Cambridge University Press.

van Hoytema N, Bednarz VN, Cardini U, Naumann MS, Al-Horani FA, Wild C. 2016. The influence of seasonality on benthic primary production in a Red Sea coral reef. Mar Biol 163:1-14

Vitousek PM, Howarth RW. 1991. Nitrogen limitation on land and in the sea: How can it occur? Biogeochemistry 13:87-115.

Wiebe WJ, Johannes RE, Webb KL. 1975. Nitrogen-fixation in a coral-reef community. Science 188:257-9.

Wilkinson CR, Sammarco PW, Trott LA. 1985. Seasonal and fish grazing effects on rates of nitrogen fixation on coral reefs (Great Barrier Reef, Australia). In: Gabrie C, Salvat B, Eds. The fifth international coral reef congress. Tahiti, pp 61-66.

Wilson ST, Böttjer D, Church MJ, Karl DM. 2012. Comparative assessment of nitrogen fixation methodologies, conducted in the oligotrophic north pacific ocean. Appl Environ Microbiol 78:6516-23.

Wooldridge SA. 2009. Water quality and coral bleaching thresholds: formalising the linkage for the inshore reefs of the Great Barrier Reef, Australia. Mar Pollut Bull 58:745-51. 